\title{
Relaçáo entre Ritmo Circadiano, Turno e Rendimento Escolar de Alunos do Ensino Fundamental - Editorial
}

\author{
Marcos Felipe Camarinha de Almeida \\ Médico Neurologista, Residente de Neurofisiologia Clínica, Escola Paulista de Medicina (EPM), \\ Universidade Federal de São Paulo (Unifesp), São Paulo-SP, Brasil.
}

Os seres humanos apresentam diferenças interindividuais em seus ritmos biológico. O perfil do ritmo circadiano é parcialmente moldado geneticamente, ou seja, alguns genes são responsáveis pelos diferentes ritmos de sono/vigília nos humanos ${ }^{1}$. Esses mesmos genes influenciam outros aspectos da homeostase corporal, tais como a temperatura e os níveis de melatonina, os quais, também, contribuem na dinâmica do ritmo circadiano. Esses fatores determinam o cronótipo do indivíduo, que pode apresentar características matutinas ou vespertinas extremas ou formas intermediárias.

A matutinidade ou a vespertinidade são características resultantes do funcionamento do sistema de temporização circadiano intrínseco, herdado geneticamente, e sofrem uma adaptação às condições ambientais ${ }^{2}$. Com relação a essas condiçóes, no que diz respeito à organização social humana, a maioria das atividades trabalhistas e educacionais ocorre entre $8 \mathrm{~h}$ e $18 \mathrm{~h}$, de forma a impor uma determinada temporalidade que favorece um melhor desempenho dos indivíduos que estão sincronizados a este horário. Porém, parte da população está biologicamente sincronizada em horários incomuns e vive num estado dessincronizado aos horários sociais ${ }^{2}$. Com relação à faixa etária, a mudança mais acentuada no padrão do ciclo sono vigília ocorre na adolescência, provavelmente secundário a mudanças hormonais decorrentes da puberdade. A maioria das crianças com idade até 10 anos apresenta um cronótipo matutino, enquanto que na puberdade, se torna mais vespertino ${ }^{1}$. Os adolescentes passam a apresentar um atraso no horário de dormir e dificuldades para acordar cedo. Dessa forma, quando se encontram no período escolar, frequentemente queixam-se de sonolência diurna e dificuldades de dormir cedo, resultando numa redução do número de horas de sono, que são compensadas nos finais de semana, além de mudança nos hábitos de sono ${ }^{1,3}$. Já na fase adulta, o período matutino retorna como preferencial para as realizaçôes de atividades intelectuais e esportivas ${ }^{1}$.

De acordo com alguns estudos, a privação de sono ou um sono de má qualidade podem comprometer os processos de memorização e de raciocínio lógico, uma vez que informaçôes aprendidas são mais eficientemente memorizadas após um período adequado de sono. Acredita-se que parte desse processo de consolidação da memória ocorra durante o estágio de sono REM (do inglês "rapid eye moviment" - movimentos oculares rápidos) $)^{4}$. A diferença de resultados obtidos em testes cognitivos pode ser explicada, também, pelo perfil do cronótipo (matutino ou vespertino). Os indivíduos com o perfil matutino apresentam melhores resultados nos testes quando os realizam pela manhã, porém reduzem a qualidade de seus desempenhos durante o decorrer do dia. Já os indivíduos com perfil vespertino fazem o caminho oposto, apresentando rendimentos mais baixos pela manhã e melhorando gradualmente com o passar do dia 5 . Outro estudo, feito por Carvalho et al., que teve como objetivo verificar a influência do horário de início da aula sobre a cognição, comparando alunos de 7 a 10 anos portadores de distúrbios respiratórios relacionados ao sono com crianças normais, foi observado que os distúrbios respiratórios do sono, como fator isolado, não exerciam influência sobre a cognição, porém, quando avaliados em conjunto com a série escolar e o horário de início da aula, observou-se prejuízo na cognição ${ }^{6}$.

Neste número da Revista Neurociências, no artigo "Relação entre ritmo circadiano, turno e rendimento 
escolar de alunos do Ensino Fundamental”, os autores investigaram uma correlação entre o ritmo circadiano, o turno escolar e o rendimento escolar de adolescentes de escolas públicas do município de Farroupilha/RS7. Participaram do estudo 478 (quatrocentos e setenta e oito) estudantes de 11 a 14 anos do ensino fundamental, provenientes de cinco escolas públicas da cidade de Farroupilha/RS. Os alunos foram avaliados pela Escala do Ritmo Circadiano - Ciclo Vigília/Sono para adolescentes e por um questionário criado pelos próprios autores referente às atividades realizadas fora da sala de aula. A primeira escala aplicada tinha o intuito de classificar os alunos em cronótipo matutino ou vespertino e a segunda com objetivo de averiguar se havia alguma relação entre as atividades realizadas fora da sala de aula e o ritmo circadiano dos estudantes. Além disso, foram registradas as notas obtidas pelos alunos durante o ano letivo em diversas disciplinas do ensino fundamental. Os autores fizeram a confrontação desses dados e chegaram à conclusão de que o grupo dos alunos matutinos, que estudavam de manhã, apresentava o melhor rendimento escolar. Nas comparaçóes por gênero, destacou-se o grupo feminino em ambos os cronótipos ${ }^{7}$.

Vários trabalhos semelhantes ao apresentado por Finimundi et al. ${ }^{7}$ são encontrados na literatura, procurando entender a relação entre o perfil do ritmo circadiano e o desempenho cognitivo. Alguns trabalhos avaliam a influência do cronótipo no rendimento escolar e outros a flutuação diária dos rendimentos em testes cognitivos nos diferentes perfis (matutino e vespertino). Esses trabalhos são de extrema relevância e devem ser incentivados com o objetivo de traçar novos planos na eduaçáo brasileira, adequando o ensino ao perfil do estudante e não o con- trário como encontramos hoje em dia, onde os alunos são forçados a seguirem uma rotina de horários que, para alguns, pode ser prejudicial tendo em vista as diferentes características dos cronótipos. Esses estudos ainda podem ser ampliados, no intuito de investigar diferentes métodos de ensino, horários preferenciais para aplicação de provas, horário ideal do início da primeira aula, entre outros aspectos.

\section{REFERÊNCIAS}

1.Randlera C, Frech D. Young people's time-of-day preferences affect their school performance. J Youth Studies 2009;12(6):653-667.

http://dx.doi.org/10.1080/13676260902902697

2.Pereira DS, Tufik S, Pedrazzoli M. Timekeeping molecules: implications for circadian phenotypes. Rev Bras Psiquiatr 2009;31(1):63-71.

http://dx.doi.org/10.1590/S1516-44462009000100015

3.Silva TA, Carvalho LBC, Silva L, Medeiros M, Natale VB, Carvalho JEC, Prado LBF, Prado GF. Sleep habits and starting time to school in Brazilian children. Arq Neuropsiquiatr 2005;63(2-B):402-406.

http://dx.doi.org/10.1590/S0004-282X2005000300007

4.Boscolo RA, Sacco IC, Antunes HK, de Mello MT, Tufik S. Avaliaçấo do padrāo de sono, atividade física e funçôes cognitivas em adolescentes escolares. Rev Port Cien Desp 2007;7(1):18-25.

5.Clarisse R, Le Floc'h N, Kindelberger C, Feunteun P. Daily rhythmicity of attention in morning- vs. evening-type adolescents at boarding school under different psychosociological testing conditions. Chronobiol Int 2010;27(4):826-841.

http://dx.doi.org/10.3109/07420521003794051

6.Carvalho LBC, Prado LF, Silva L, Almeida MM, Silva TA, Lora MI, Prado GF. Cognitive dysfunction in children with sleep-disordered breathing. J Child Neurol 2005;20:400-404.

http://dx.doi.org/10.1177/08830738050200050101

7.Finimundi M, Rico EP, Souza DO. Relaçấo Entre Ritmo Circadiano, Turno e Rendimento Escolar de Alunos do Ensino Fundamental. Rev Neurocienc 2013;21(2):175-183.

http://dx.doi.org/10.4181/RNC.2013.21.805.9p 